\title{
Editorial
}

\section{International Archives of Otorhinolaryngology}

\section{Editorial - The Dissemination of Scholarly Journals: Print or Electronic?}

Volume 16 (3) - July/August/September - 2012

\section{Dear Reader,}

In this globalized world where science advances daily, scientific journals have an important role in this process, materializing discoveries and sedimenting knowledge. The International Archives of Otolaryngology is more one of these alternatives, making room for in the related field publications and related, disseminating clinical and basic science research.

The current advantages that help scientists to disseminate their research is the presence of electronic media to support their dissemination, as well as the scope of the worldwide.

Nowadays we can even discuss how to better assess the real needs of our making available scientific content and how to use strategic model, because we understand there is no competition between the two media, but using different tools where the print is restricted to subscribers and electronics in contrast, is available to the worldwide network.

The strategy of working with both the magazine and the site must come to add, as a way of marketing the product print, attempting to break the stagnation of the magazine, while enhancing the partnership with the electronic media.

We are happy to receive your visit to our site:

http://www.internationalarchivesent.org

We hope to see you in future publications.

A big hug,

\author{
Geraldo Pereira Jotz \\ Editor-in-Chief \\ International Archives of Otorhinolaryngology
}

